\title{
Differential recovery of PSII function and electron transport rate in symbiotic dinoflagellates as a possible determinant of bleaching susceptibility of corals
}

\author{
Irina Yakovleva ${ }^{1,2, *}$, Michio Hidaka ${ }^{1}$
}

\footnotetext{
${ }^{1}$ Department of Chemistry, Biology and Marine Science, University of the Ryukyus, Nishihara, Okinawa 903-0213, Japan

${ }^{2}$ Institute of Marine Biology, Far East Branch of Russian Academy of Sciences, Vladivostok 690041, Russia
}

\begin{abstract}
Differences in the time course of recovery of the photochemical efficiency $\left(F_{\mathrm{v}} / F_{\mathrm{m}}\right)$ of PSII and the photosynthetic capacity (relative maximum electron transport rate; $\mathrm{rETR}_{\max }$ ), of symbiotic dinoflagellates from damage due to thermal and light stresses might have profound effects on the subsequent photodamage of photosynthetic apparatus. The reduction and recovery of $F_{\mathrm{v}} / F_{\mathrm{m}}$ and $\mathrm{rETR}_{\max }$ in symbiotic dinoflagellates were investigated at different temperatures $\left(25,28\right.$ and $\left.31^{\circ} \mathrm{C}\right)$ after $3 \mathrm{~h}$ exposure to high light $\left(1100 \mu \mathrm{mol}\right.$ photons $\mathrm{m}^{-2} \mathrm{~s}^{-1}$ of photosynthetically active radiation [PAR]) in 2 corals with different bleaching susceptibility, Pavona divaricata and Montipora digitata. There was a marked difference in both the reduction in $\mathrm{rETR}_{\max }$ after high light exposure and the time course of its recovery between $P$. divaricata and $M$. digitata. In P. divaricata, the reduction in $F_{\mathrm{v}} / F_{\mathrm{m}}$ and $\mathrm{rETR}_{\max }$ during high light exposure was independent of temperature, and their recovery was almost complete within $24 \mathrm{~h}$ after stress treatment at all temperatures examined. In M. digitata, while the reduction and recovery of $F_{\mathrm{v}} / F_{\mathrm{m}}$ did not show temperature dependency, $\mathrm{rETR}_{\max }$ exhibited a greater decrease and lower recovery at $31^{\circ} \mathrm{C}$ than at 25 and $28^{\circ} \mathrm{C}$. The recovery of $\mathrm{rETR}_{\max }$ was slower than that of $F_{\mathrm{v}} / F_{\mathrm{m}}$ in symbiotic dinoflagellates of $M$. digitata, and this delay of $\mathrm{rETR}_{\max }$ recovery increased with increasing temperature during the recovery period. Significant decreases in dinoflagellate density and chlorophyll content were evident only in the $31^{\circ} \mathrm{C}$-treated fragments of $M$. digitata kept at $31^{\circ} \mathrm{C}$ during the recovery period. These results indicate that it is the difference in the rate of recovery between the PSII function and the dark reaction of symbiotic dinoflagellates that determines whether the photosynthetic ability of algae recovers from the combined effect of thermal and irradiance stresses. The delayed recovery of $\mathrm{rETR}_{\max }$ at high temperature made fragments of $M$. digitata susceptible to photodamage even under moderate light conditions. $P$. divaricata showed a high ability to recover its $\mathrm{rETR}_{\max }$ and consequently was resistant to high light and thermal stresses. It is likely that high temperature affects the rate of recovery of the carbon-fixation cycle and that the ability of symbiotic dinoflagellates to repair damage determines susceptibility of corals to bleaching.
\end{abstract}

KEY WORDS: Bleaching $\cdot$ Coral $\cdot$ Symbiotic dinoflagellate $\cdot$ PAM $\cdot$ Photosystem II $\cdot$ ETR

\section{INTRODUCTION}

Coral bleaching, discoloration of corals due to loss of symbiotic algae (dinoflagellates) and/or algal pigments, can be caused by a variety of stresses, but large-scale bleaching events are generally ascribed to thermal stress and solar radiation (Brown 1997, Hoegh-Guldberg 1999, Fitt \& Cook 2001). A slight increase in seawater temperature $\left(1-2^{\circ} \mathrm{C}\right)$ above normal summer maxima can induce bleaching of corals (e.g. Glynn 1993, Brown 1997, Hoegh-Guldberg 1999). High temperature is considered to make algal symbionts more sensitive to photoinhibition of photosynthesis by solar radiation and resulting photodamage of algae leads to bleaching (Warner et al. 1996, 1999, Lesser 1997, Jones et al. 1998, 2000). 
Photoinhibition is classified as being either dynamic or chronic. Dynamic photoinhibition due to damage of the D1 protein, which is normally repaired within several hours, is considered as photoprotective, as the damaged reaction centers continue to trap excitation energy but dissipate it as heat (Krause 1988). Chronic photoinhibition involves irreversible photodamage to photosystem II (PSII) via degradation of the D1 protein and other PSII proteins (Krause 1988, Demmig-Adams \& Adams 1992), where repair mechanisms may take many hours or days (Bose et al. 1988). Extended exposure of corals to high temperature and strong light causes long-term reduction in photochemical efficiency, $F_{\mathrm{v}} / F_{\mathrm{m}}$, resulting in its slow and incomplete recovery, and is associated with bleaching (Fitt \& Warner 1995, Warner et al. 1996, 1999, Jones et al. 2000, Bhagooli \& Hidaka 2002, Brown et al. 2002). A decline in the D1 reaction center protein in symbiotic dinoflagellates found in bleached corals has also been reported (Warner et al. 1999). These observations indicate that symbiotic dinoflagellates in naturally bleached corals are suffering from chronic photoinhibition. However, most laboratory studies on the effect of thermal stress in symbiotic dinoflagellates have typically been concentrated on rather short-term changes in the photochemical efficiency of PSII or light curve of photosynthesis (Iglesias-Prieto et al. 1992, Fitt \& Warner 1995, IglesiasPrieto 1997, Lesser 1997, Jones et al. 1998, Warner et al. 1999). There is a limited number of long-term studies on the recovery process of the photochemical efficiency of PSII (Jones et al. 2000, Saxby et al. 2003) in corals following combined thermal and light stress treatment, and the effects of temperature on the recovery of electron transport rate of symbiotic dinoflagellates or both parameters together are yet to be explored.

Thermal stress affects both light and dark reactions of photosynthesis in symbiotic algae (e.g. Warner et al. 1996, 1999, Igresias-Prieto 1997, Lesser 1997, Jones et al. 1998, 2000, Hoegh-Guldberg 1999). According to Warner et al. (1999), heat stress causes damage to PSII via degradation of the D1 protein because the rate of its degradation is greater than that of its re-synthesis at high temperature. On the other hand, based on Jones et al. (1998), Hoegh-Guldberg (1999) proposed a 'photoinhibition' model for coral bleaching. According to their model, the onset of coral bleaching begins by the impairment of carbon fixation in dinoflagellates, subsequent slowdown of the electron transport from PSII to the Calvin-Benson cycle, and hence, overreduction of the light reactions under elevated temperature and high light. Thus, there are still debates on the primary site of action of thermal stress and whether damage of PSII or the carbon-fixation cycle is a determinant of coral bleaching (e.g. Hoegh-Guldberg 1999, Warner et al. 1999).
If the above 'photoinhibition' hypothesis of bleaching is correct, the relative recovery rates of PSII function and the carbon-fixation cycle would have significant effects on the photodamage of symbiotic dinoflagellates in corals ('differential recovery' hypothesis). If the recovery of the carbon-fixation cycle is slower than that of PSII, high-energy electrons generated by photochemical reaction in PSII cannot be fully consumed in the Calvin-Benson cycle even under subsaturation irradiance. The reduced photosynthetic electron transport combined with continued absorption of excitation energy may lead to production of active oxygen molecules, which cause damage or inactivation of photosynthetic components (including PSII) of symbiotic dinoflagellates. If the damage is severe and long lasting, corals will eventually bleach.

To test the differential recovery hypothesis, we studied the effects of temperature on the reduction and the rate of recovery of photochemical efficiency, $F_{\mathrm{v}} / F_{\mathrm{m}}$ of PSII and of the relative photosynthetic electron transport rate (photosynthetic capacity), rETR, in symbiotic dinoflagellates associated with a bleaching-susceptible coral, Montipora digitata (Loya et al. 2001), and a resistant coral, Pavona divaricata (Sakai pers. comm.), after $3 \mathrm{~h}$ exposure to high light. At the same time, dinoflagellate density and chlorophyll (Chl) content were measured to detect signs of bleaching in the corals during the experiments.

\section{MATERIALS AND METHODS}

Collection and maintenance of corals. Colonies of Pavona divaricata (Lamarck 1816) and Montipora digitata (Dana 1846) were collected from a depth of 0.2 to $0.5 \mathrm{~m}$ during low tide at Bise and the eastern reef of Sesoko Island, Okinawa, Japan. Colonies were kept in an outdoor tank supplied with running seawater for a few weeks until use. During this period, seawater temperature in the tank was $21-22^{\circ} \mathrm{C}$ and incident photosynthetically active radiation (PAR) did not exceed $1100 \mu \mathrm{mol}$ photons $\mathrm{m}^{-2} \mathrm{~s}^{-1}$. The tank was shaded by black plastic mesh to reduce the light intensity to $10 \%$ of incident PAR.

Experimental design. The experiments were conducted during January-February 2002. Branches about $3 \mathrm{~cm}$ in length were taken from colonies of Montipora digitata, and fragments about $4 \mathrm{~cm}^{2}$ of tissue surface area were removed from Pavona divaricata. Four replicate colonies were used for each species. Fifty-one fragments were prepared from each coral colony, and mounted on glass slides using rubber bands. Fragments from 4 replicate colonies were divided into 3 groups $(36,68$, and 100 fragments for the first, second, and third groups, respectively). Fragments of each 
group were placed into each of 3 aquaria containing aerated seawater. Temperature in the aquarium for the first group was maintained at $25^{\circ} \mathrm{C}$. The seawater temperature in the aquaria for the second and third groups was increased gradually $\left(0.5\right.$ to $\left.1^{\circ} \mathrm{C} \mathrm{d}^{-1}\right)$ from $25^{\circ} \mathrm{C}$ up to 28 and $31^{\circ} \mathrm{C}$, respectively, over a $5 \mathrm{~d}$ period (Fig. 1). The temperature was regulated using automatic thermostats $\left( \pm 0.5^{\circ} \mathrm{C}\right.$, IC Thermostat, EX-003) and aquarium heaters. The coral fragments were illuminated at a light intensity of $70 \mu \mathrm{mol}$ photons $\mathrm{m}^{-2} \mathrm{~s}^{-1}$ with 3 white fluorescent lamps (National, FL20SS-N/18) during day time (12 h). Half of the seawater in the aquaria was replaced every third day with fresh seawater adjusted to respective temperatures during the experimental period.

After a $5 \mathrm{~d}$ acclimation period, the initial measurements of chl a fluorescence parameters, Chl content and dinoflagellate density were performed with 4 fragments each from different colonies for both species. Half of the remaining fragments were placed in transparent plastic chambers $(30 \mathrm{~cm} \times 40 \mathrm{~cm})$ containing aerated seawater and used as the experimental units. The other half of the fragments were left in the aquaria at the respective acclimation temperatures under low white light as the controls. The chambers with experimental fragments were put into one of the water baths whose temperature was regulated at 25, 28 and $31^{\circ} \mathrm{C}$ by temperature control units (EYELA, Thermister Tempet T-80). The experimental fragments were exposed to $1100 \mu \mathrm{mol}$ photons $\mathrm{m}^{-2} \mathrm{~s}^{-1}$ of PAR (similar to those in the field in midday winter sunlight) for $3 \mathrm{~h}$, as shown in Fig. 1. PAR treatment was carried out using two $500 \mathrm{~W}$ incandescent lamps (NIKKO). Visible irradiance was measured using a light meter (LICOR, LI-250). After $3 \mathrm{~h}$ exposure to high light, the samples were allowed to recover at different temperatures under low light $\left(70 \mu \mathrm{mol}\right.$ photons $\left.\mathrm{m}^{-2} \mathrm{~s}^{-1}\right)$. Fluorescence kinetics, $\mathrm{Chl}$ content and dinoflagellate density were measured before, immediately after light exposure and then after 24,72 and $120 \mathrm{~h}$ of recovery approximately at the same time of the day (Fig. 1). Control fragments were exposed to the same temperature treatment as the experimental ones but were kept under low light $\left(70 \mu \mathrm{mol}\right.$ photons $\mathrm{m}^{-2} \mathrm{~s}^{-1}$ ) during the daytime throughout the experimental period.

Chl a fluorescence measurements. Chl fluorescence was measured using a pulse-amplitudemodulation fluorometer (MINI-PAM). Coral fragments were taken from the experimental chamber or aquarium and placed in a custom-made black box with filtered $(0.45$ $\mu \mathrm{m})$ seawater and dark adapted for $20 \mathrm{~min}$. The initial fluorescence $\left(F_{0}\right)$ was measured by exposing the coral to weak red light $\left(<1 \mu \mathrm{mol}\right.$ photons $\left.\mathrm{m}^{-2} \mathrm{~s}^{-1}\right)$. Maximum fluorescence $\left(F_{\mathrm{m}}\right)$ was determined by applying a $0.8 \mathrm{~s}$ saturation pulse of intense white light $(8000 \mu \mathrm{mol}$ photons $\left.\mathrm{m}^{-2} \mathrm{~s}^{-1}\right)$. The ratio of variable $\left(F_{\mathrm{v}}\right)$ to maximum fluorescence $\left(F_{\mathrm{m}}\right), F_{\mathrm{v}} / F_{\mathrm{m}}$, was used as an indicator of the maximum potential quantum yield. The dark-adapted quantum yield $\left(F_{\mathrm{v}} / F_{\mathrm{m}}\right.$ i Schreiber et al. 1994), provides a good approximation of the maximum photochemical efficiency of PSII (Oquist et al. 1992). The $F_{\mathrm{v}} / F_{\mathrm{m}}$ values of coral fragments before stress treatment ranged from 0.56 to 0.68 (Table 1), typical of those in corals experiencing no damage to PSII (e.g. Fitt et al. 2001). Immediately after $F_{\mathrm{v}} / F_{\mathrm{m}}$ measurement, $5 \mathrm{~min}$ of $500 \mu \mathrm{mol}$ photons $\mathrm{m}^{-2} \mathrm{~s}^{-1}$ (saturated light for photosynthesis of the species under investigation) from the Mini-PAM internal halogen lamp was applied to activate photosynthetic dark reactions followed by a 30 s dark period, and then rapid light curves were recorded: samples were irradiated with increasing irradiance (photon flux density, $\mathrm{PFD}=100$ to $1300 \mu \mathrm{mol}$ photons $\mathrm{m}^{-2} \mathrm{~s}^{-1}$ ). Every $20 \mathrm{~s}$, a saturating pulse was applied to measure effective quantum yield of PSII $\left(\Delta F / F_{\mathrm{m}}{ }^{\prime}\right)$ before irradiation was further increased. Respective rETR were determined by multiplying the effective quantum yield with the respective photon irradiance (Schreiber et al. 1994). The rETR values given here are relative because we did not consider the fraction of light 
Table 1. Pavona divaricata and Montipora digitata. Physiological parameters (means $\pm \mathrm{SD} ; \mathrm{n}=4$ ) of symbiotic dinoflagellates after $5 \mathrm{~d}$ acclimation at 25 , 28 and $31^{\circ} \mathrm{C}$ under $70 \mu \mathrm{mol}$ photons $\mathrm{m}^{-2} \mathrm{~s}^{-1}$. ${ }^{*}$ Significantly different from $25^{\circ} \mathrm{C}$-acclimated corals (Tukey-Kramer HSD test, $\mathrm{p}<0.05$ )

\begin{tabular}{|c|c|c|c|c|}
\hline & $F_{\mathrm{v}} / F_{\mathrm{m}}$ & 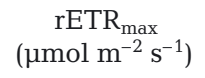 & $\begin{array}{l}\text { Chl }\left(a+C_{2}\right) \\
\left(p g \text { cell }^{-1}\right)\end{array}$ & $\begin{array}{c}\text { Density } \\
\left(10^{6} \text { ind. } \mathrm{cm}^{-2}\right)\end{array}$ \\
\hline \multicolumn{5}{|c|}{ Pavona divaricata } \\
\hline $31^{\circ} \mathrm{C}$ & $0.62 \pm 0.03$ & $1.76 \pm 0.19^{*}$ & $9.6 \pm 1.1^{*}$ & $1.75 \pm 0.13$ \\
\hline $28^{\circ} \mathrm{C}$ & $0.65 \pm 0.04$ & $2.47 \pm 0.19$ & $16.7 \pm 3.3$ & $1.79 \pm 0.12$ \\
\hline $25^{\circ} \mathrm{C}$ & $0.68 \pm 0.02$ & $2.43 \pm 0.36$ & $16.0 \pm 3.2$ & $2.05 \pm 0.15$ \\
\hline \multicolumn{5}{|c|}{ Montipora digitata } \\
\hline $31^{\circ} \mathrm{C}$ & $0.60 \pm 0.03$ & $1.82 \pm 0.02^{*}$ & $13.0 \pm 1.2^{*}$ & $1.01 \pm 0.08^{*}$ \\
\hline $28^{\circ} \mathrm{C}$ & $0.62 \pm 0.04$ & $1.72 \pm 0.06$ & $9.8 \pm 0.8$ & $1.32 \pm 0.11$ \\
\hline $25^{\circ} \mathrm{C}$ & $0.58 \pm 0.03$ & $1.53 \pm 0.09$ & $9.9 \pm 0.5$ & $1.40 \pm 0.07$ \\
\hline
\end{tabular}

For measurements of dinoflagellate density, $30 \mathrm{ml}$ of the homogenate was centrifuged at $1250 \times g$ for $15 \mathrm{~min}$. The pellet was re-suspended and the volume was adjusted to $1 \mathrm{ml}$. Counting was performed on eight $1 \mathrm{~mm}^{2}$ squares on a hemocytometer for each sample. Only healthy-looking symbiotic dinoflagellates (Titlyanov et al. 1996) were counted. Microscopic observations were made under $400 \times$ magnification using a Nikon OPTIPHOT-2 microscope. The surface area of coral fragments was determined by the paraffin-wax technique (Stimson \& Kinzie 1991). Symbiotic algal density was expressed as a number of algae per unit

absorbed by the photosynthetic pigments of the zooxanthellae within the coral tissue (see also Hoegh-Guldberg \& Jones 1999, Winters et al. 2003) or the distribution of absorbed light between pigments associated with 2 photosystems. rETR $_{\max }$ was calculated by regression analysis. Our preliminary experiments revealed that $\mathrm{rETR}$ and $\mathrm{O}_{2}$ evolution showed a significantly linear correlation at irradiance up to 500-550 $\mu \mathrm{mol}$ photons $\mathrm{m}^{-2} \mathrm{~s}^{-1}$ of incident PAR in both coral species $\left(\mathrm{r}^{2}=0.87\right.$ and $\mathrm{r}^{2}=0.90$ for Montipora digitata and Pavona divaricata, respectively). Thus, the $\mathrm{rETR}_{\max }$ values, which were usually attained at $470 \mu \mathrm{mol}$ photons $\mathrm{m}^{-2} \mathrm{~s}^{-1}$ in the present study, represented a good measure of the maximal photosynthetic capacity of symbiotic dinoflagellates in the coral species investigated. The $\mathrm{rETR}_{\max }$ values were normalized to dinoflagellate density $\left(10^{6}\right.$ cells $)$ by dividing the ETR $_{\max }$ value by actual dinoflagellate cell number in each measured coral fragment, so that changes in photosynthetic capacity of an algal cell remaining in the host tissue could be compared among different stress treatments. The measurements of chlorophyll fluorescence were done at the treatment temperatures: 25,28 and $31^{\circ} \mathrm{C}$.

Determination of $\mathrm{Chl}$ content and symbiotic dinoflagellate density. Coral fragments were rinsed gently with filtered seawater (FSW), and then coral tissue was removed from the coral skeleton by water picking with FSW (Johannes \& Wiebe 1970). The coral blastate (70 to $120 \mathrm{ml}$ ) was then homogenized with a potter homogenizer, and a $30 \mathrm{ml}$ aliquot was filtered under vacuum through a Whatman GF/C glass-fiber filter $(47 \mathrm{~mm}$ in diameter). The glass-fiber filters with adsorbed symbiotic algae were immersed in an aqueous solution of $90 \%$ acetone and placed in a refrigerator for $2 \mathrm{~d}$. The solution with sample was shaken daily. The absorbance of acetone extracts was measured at 630, 663 and $750 \mathrm{~nm}$ using a Hitachi U-2001 spectrophotometer. The concentrations of chl $a$ and $c_{2}$ were determined using the equations of Jeffrey \& Humphrey (1975). surface area. The symbiotic dinoflagellate density and Chl content were measured for 4 coral fragments from the 4 respective colonies in each treatment.

Statistical analyses. Differences between mean values of experimental and control fragments and the comparisons of $F_{\mathrm{v}} / F_{\mathrm{m}}$ and $\mathrm{rETR}_{\max }$ recoveries at different temperatures or at different times after high light stress were analyzed using a $t$-test. The effects of temperature on $F_{\mathrm{v}} / F_{\mathrm{m}}, \mathrm{rETR}$ max , dinoflagellate density and Chl content after high light exposure and during the recovery period were assessed by ANOVA. When ANOVA showed significant differences, the TukeyKramer HSD test was performed for multiple comparisons among means. Arcsine transformation was applied to proportional data prior to ANOVA. The amount of influence of temperature was analyzed with the Snedekor function (SF, Snedecor 1961), and the significance of values was evaluated by the Fisher test at the $\mathrm{p}=0.05$ level. The effects of temperature and high light on fluorescence kinetics were statistically analyzed using relative $F_{\mathrm{v}} / F_{\mathrm{m}}$ and relative $\mathrm{rETR}_{\max }$, which were normalized to the values of controls that experienced the same temperature treatment without high light exposure.

\section{RESULTS}

\section{Effects of acclimation temperatures on physiological parameters}

Coral fragments of Pavona divaricata and Montipora digitata acclimated at 25 and $28^{\circ} \mathrm{C}$ under low light for $5 \mathrm{~d}$ did not show any significant change in either $\mathrm{Chl}$ content, symbiotic dinoflagellate density, $F_{\mathrm{v}} / F_{\mathrm{m}}$, or $\mathrm{rETR}_{\max }$. However, those acclimated at $31^{\circ} \mathrm{C}$ showed significant changes in some parameters (Table 1). Fragments of $M$. digitata acclimated at $31^{\circ} \mathrm{C}$ had slightly but significantly higher $\mathrm{rETR}_{\max }$ and total Chl 
content than those acclimated at $25^{\circ} \mathrm{C}$, while $P$. divaricata fragments acclimated at $31^{\circ} \mathrm{C}$ had significantly lower $\mathrm{rETR}_{\max }$ and total $\mathrm{Chl}$ content than those acclimated at $25^{\circ} \mathrm{C}$. The dinoflagellate density was significantly lower only in $M$. digitata samples acclimated at $31^{\circ} \mathrm{C}$. The $F_{\mathrm{v}} / F_{\mathrm{m}}$ values did not differ in either corals among the thermal acclimation conditions. Hereafter values of $F_{\mathrm{v}} / F_{\mathrm{m}}, \mathrm{rETR}_{\max }$, symbiotic dinoflagellate density and $\mathrm{Chl}$ content after stress or after recovery are compared with those of non-exposed controls that were exposed to the same temperature treatment but without $3 \mathrm{~h}$ high light exposure.

\section{Changes in dark-adapted $F_{\mathrm{v}} / F_{\mathrm{m}}$ and $\mathrm{rETR}_{\max }$ after high light exposure}

\section{Photoinhibition}

The $3 \mathrm{~h}$ high light (1100 $\mu \mathrm{mol}$ photons $\left.\mathrm{m}^{-2} \mathrm{~s}^{-1}\right)$ exposure induced a significant reduction in $F_{\mathrm{v}} / F_{\mathrm{m}}$ in both Pavona divaricata and Montipora digitata. Temperature during high light exposure did not affect the extent of reduction in $F_{\mathrm{v}} / F_{\mathrm{m}}$ in both species (Fig. 2). $\mathrm{rETR}_{\max }$ also decreased significantly after $3 \mathrm{~h}$ high light exposure in both species except $P$. divaricata exposed to high light at $25^{\circ} \mathrm{C}$ (Fig. 2). The reduction in $\mathrm{rETR}_{\max }$ differed significantly (ANOVA, $\mathrm{p}<0.01$ ) between temperature treatments in $M$. digitata, while it was not affected by temperature during high light exposure in $P$. divaricata (Fig. 2). In symbiotic dinoflagellates of $M$. digitata, the $\mathrm{rETR}_{\max }$ decreased only to $70 \%$ of nonexposed control at 25 and $28^{\circ} \mathrm{C}$, while it decreased to $40 \%$ at $31^{\circ} \mathrm{C}$.

\section{Recovery under different temperature conditions}

The time course of recovery of $F_{\mathrm{v}} / F_{\mathrm{m}}$ and $\mathrm{rETR}_{\max }$ after $3 \mathrm{~h}$ exposure to high light was investigated by comparing the $F_{\mathrm{v}} / F_{\mathrm{m}}$ and $\mathrm{rETR}_{\max }$ values with those of non-exposed controls. If the $F_{\mathrm{v}} / F_{\mathrm{m}}$ and $\mathrm{rETR}_{\max }$ values returned to the level that was not significantly different from those of controls, the recovery was considered to be complete. Control coral fragments, which were maintained at the respective temperatures but without exposure to high light, showed no change ( $t$-test, $\mathrm{p}<$ 0.05) in $F_{\mathrm{v}} / F_{\mathrm{m}}$ or $\mathrm{rETR}_{\max }$ during the experimental period.

In Pavona divaricata, no significant difference between the extent of recovery of $F_{\mathrm{v}} / F_{\mathrm{m}}$ and that of $\mathrm{rETR}_{\max }$ was detected throughout the recovery period (Table 2). Both $F_{\mathrm{v}} / F_{\mathrm{m}}$ and $\mathrm{rETR}_{\max }$ recovered completely in $24 \mathrm{~h}$ after high light exposure in all cases but one (Fig. 3). Only in fragments that were kept at $31^{\circ} \mathrm{C}$

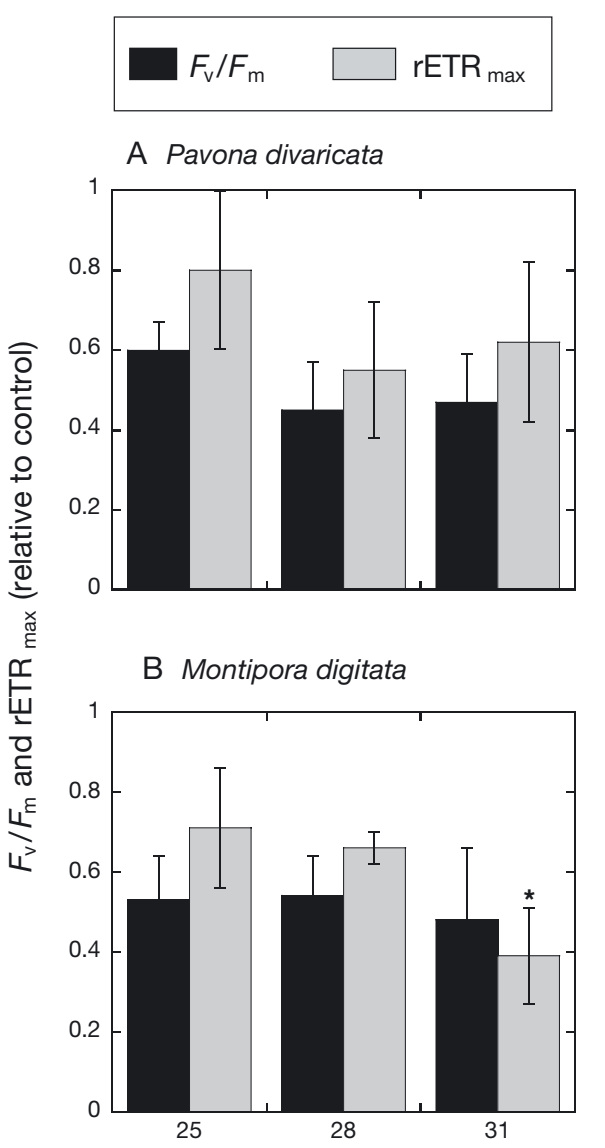

Temperature during high light exposure $\left({ }^{\circ} \mathrm{C}\right)$

Fig. 2. Effects of temperature during high light exposure on $F_{\mathrm{v}} / F_{\mathrm{m}}$ and $\mathrm{rETR}_{\max }$ in symbiotic dinoflagellates of (A) Pavona divaricata and (B) Montipora digitata. $\mathrm{rETR}_{\max }$ values were normalized to $10^{6}$ dinoflagellate cells. Relative $F_{\mathrm{v}} / F_{\mathrm{m}}$ and relative $\mathrm{rETR}_{\max }$, both of which were normalized to values of control fragments that experienced the same temperature treatment without high light exposure, are shown. Means \pm $\mathrm{SD}(\mathrm{n}=4)$. *Value significantly different from those at other temperatures (Tukey multiple comparison test, $\mathrm{p}<0.05$ )

during both high light exposure and recovery period were $F_{\mathrm{v}} / F_{\mathrm{m}}$ values slightly but significantly $(\mathrm{p}<0.05)$ less than those in the non-exposed control $24 \mathrm{~h}$ after the stress treatment. ANOVA showed that temperature during the recovery period did not have significant effect (ANOVA, $F_{F_{\mathrm{v}} / F_{\mathrm{m}}}=0.11, F_{\mathrm{rETRmax}}=2.16$, $\mathrm{p}>0.05$ ) on both $F_{\mathrm{v}} / F_{\mathrm{m}}$ and $\mathrm{rETR}_{\max }$ in $P$. divaricata.

In Montipora digitata, significant difference in the extent of recovery was observed between $F_{\mathrm{v}} / F_{\mathrm{m}}$ and $\mathrm{rETR}_{\max }$ at least at one sampling time during the recovery period except fragments exposed to high light at $25^{\circ} \mathrm{C}$ (Table 2 ). The $F_{\mathrm{v}} / F_{\mathrm{m}}$ recovered fully within $24 \mathrm{~h}$ after the stress treatment if the fragments exposed to high light were allowed to recover at 25 or $28^{\circ} \mathrm{C}$ (Fig. 4A,C). When the fragments exposed to high light at $31^{\circ} \mathrm{C}$ were allowed to recover at $31^{\circ} \mathrm{C}$, complete 

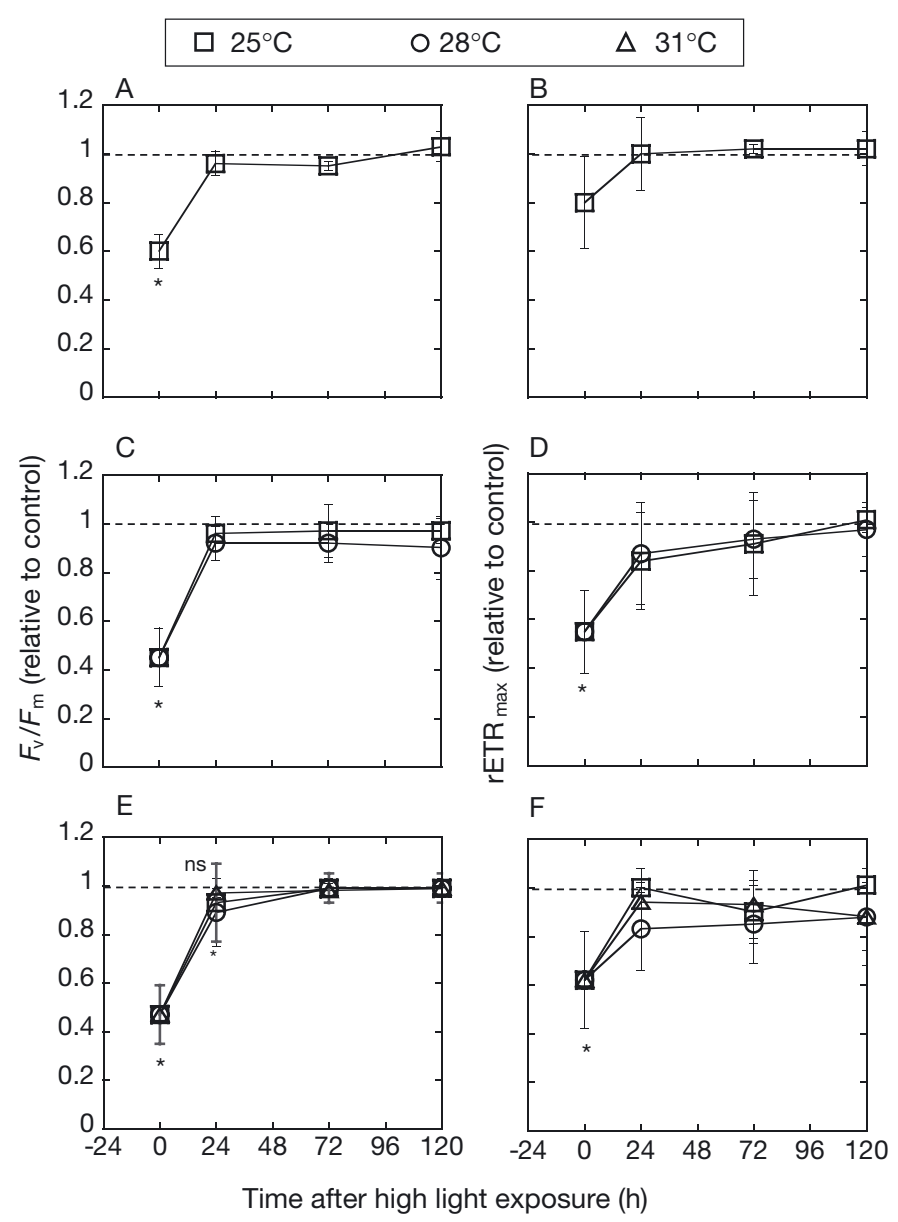

Fig. 3. Time course of recovery in $F_{\mathrm{v}} / F_{\mathrm{m}}$ and $\mathrm{rETR}_{\max }$ in symbiotic dinoflagellates of Pavona divaricata exposed to high light $\left(1100 \mu \mathrm{mol}\right.$ photons $\left.\mathrm{m}^{-2} \mathrm{~s}^{-1}\right)$ for $3 \mathrm{~h}$. The $\mathrm{rETR}_{\max }$ values were normalized to $10^{6}$ dinoflagellate cells. The relative $F_{\mathrm{v}} / F_{\mathrm{m}}$ and relative $\mathrm{rETR}_{\max }$, both of which were normalized to values of control fragments that experienced the same temperature treatment without high light exposure, are shown. Coral fragments were exposed to high light at $(\mathrm{A}, \mathrm{B}) 25,(\mathrm{C}, \mathrm{D})$ 28 , and $(\mathrm{E}, \mathrm{F}) 31^{\circ} \mathrm{C}$. Fragments were allowed to recover at 25 , 28 , and $31^{\circ} \mathrm{C}$. Means $\pm \mathrm{SD}(\mathrm{n}=4)$. *Values significantly different from controls $(t$-test, $\mathrm{p}<0.05)$. ns: not significant

recovery of $F_{\mathrm{v}} / F_{\mathrm{m}}$ was observed only in $72 \mathrm{~h}$ after the stress treatment (Fig. 4E). In contrast, recovery of $\mathrm{rETR}_{\max }$ was incomplete in $24 \mathrm{~h}$ in fragments exposed to high light at 28 or $31^{\circ} \mathrm{C}$ (Fig. 4D,F). Complete recovery of $\mathrm{rETR}_{\max }$ was attained after $72 \mathrm{~h}$ in corals exposed to high light at $28^{\circ} \mathrm{C}$. In the $31^{\circ} \mathrm{C}$-treated fragments, it took 72 and $120 \mathrm{~h}$ for $\mathrm{rETR}_{\max }$ to recover completely at 25 and $28^{\circ} \mathrm{C}$, respectively, whereas recovery was incomplete at $31^{\circ} \mathrm{C}$ recovery temperature even after $120 \mathrm{~h}$ in low light. Thus, the delay in the recovery of $\mathrm{rETR}_{\max }$ increased with increasing temperature during the recovery period. Temperature during the recovery period had a significant effect on the recovery of
Table 2. Comparison between percentage of recovery of $F_{\mathrm{v}} / F_{\mathrm{m}}$ and that of $\mathrm{rETR}_{\max }$ in symbiotic dinoflagellates of Montipora digitata and Pavona divaricata at different times after high light exposure. ${ }^{*}$ Significant difference $(t$-test, $\mathrm{p}<0.05)$. ns: not significant

\begin{tabular}{|c|c|c|c|c|}
\hline \multirow{3}{*}{$\begin{array}{l}\text { Temperature } \\
\text { during high light } \\
\text { exposure }\left({ }^{\circ} \mathrm{C}\right) \\
\text { Montipora diqita }\end{array}$} & \multirow{2}{*}{$\begin{array}{l}\text { Temperature } \\
\text { during } \\
\text { recovery }\left({ }^{\circ} \mathrm{C}\right)\end{array}$} & \multicolumn{3}{|c|}{$F_{\mathrm{v}} / F_{\mathrm{m}}-\mathrm{rETR}_{\max }$} \\
\hline & & $24 \mathrm{~h}$ & $72 \mathrm{~h}$ & $120 \mathrm{~h}$ \\
\hline & \\
\hline \multirow[t]{3}{*}{31} & 31 & ns & $*$ & * \\
\hline & 28 & $*$ & $*$ & $\mathrm{~ns}$ \\
\hline & 25 & $*$ & $\mathrm{~ns}$ & ns \\
\hline \multirow[t]{2}{*}{28} & 28 & $*$ & $\mathrm{~ns}$ & ns \\
\hline & 25 & $*$ & $\mathrm{~ns}$ & $\mathrm{~ns}$ \\
\hline 25 & 25 & ns & ns & ns \\
\hline \multicolumn{5}{|l|}{ Pavona divaricata } \\
\hline \multirow[t]{3}{*}{31} & 31 & ns & ns & $\mathrm{ns}$ \\
\hline & 28 & ns & ns & ns \\
\hline & 25 & $\mathrm{~ns}$ & $\mathrm{~ns}$ & $\mathrm{~ns}$ \\
\hline \multirow[t]{2}{*}{28} & 28 & ns & ns & $\mathrm{ns}$ \\
\hline & 25 & ns & $\mathrm{ns}$ & $\mathrm{ns}$ \\
\hline 25 & 25 & ns & $\mathrm{ns}$ & $\mathrm{ns}$ \\
\hline
\end{tabular}

$\mathrm{rETR}_{\max }$ only in the $31^{\circ} \mathrm{C}$-treated fragments of $M$. digitata (ANOVA, $F=35.97$, p < 0.01), providing $59.9 \%$ (SF: $p=0.0039$ ) of its variation, while it produced no significant effect on the recovery of $F_{\mathrm{v}} / F_{\mathrm{m}}$.

\section{Changes in $\mathrm{Chl}$ content and symbiotic dinoflagellate density in response to high light exposure}

Changes immediately after high light exposure

After $3 \mathrm{~h}$ high light exposure, the total Chl content in symbiotic dinoflagellates of Montipora digitata decreased significantly $(\mathrm{p}<0.05)$ at all temperature conditions (Fig. 5). The reduction in the total Chl content was smaller at $25^{\circ} \mathrm{C}$ than at 28 and $31^{\circ} \mathrm{C}$, representing a decrease up to 15 and $40 \%$ of non-exposed control, respectively. In symbiotic dinoflagellates of Pavona divaricata, exposure to high light at 28 and $31^{\circ} \mathrm{C}$ caused significant $(\mathrm{p}<0.05)$ decrease in the total $\mathrm{Chl}$ content by 30 to $35 \%$, though no significant changes in the total $\mathrm{Chl}$ content were detected in fragments exposed to high light at $25^{\circ} \mathrm{C}$ (Fig. 5). Temperature during high light exposure significantly affected the total Chl content in symbiotic dinoflagellates of $M$. digitata and $P$. divaricata (ANOVA: $F=14.68$, $\mathrm{p}<0.01$, and $F=16.11, \mathrm{p}<0.01$, respectively).

There were no significant $(t$-test, $\mathrm{p}<0.05)$ differences in symbiotic dinoflagellate density between fragments exposed to high light exposure for $3 \mathrm{~h}$ and 


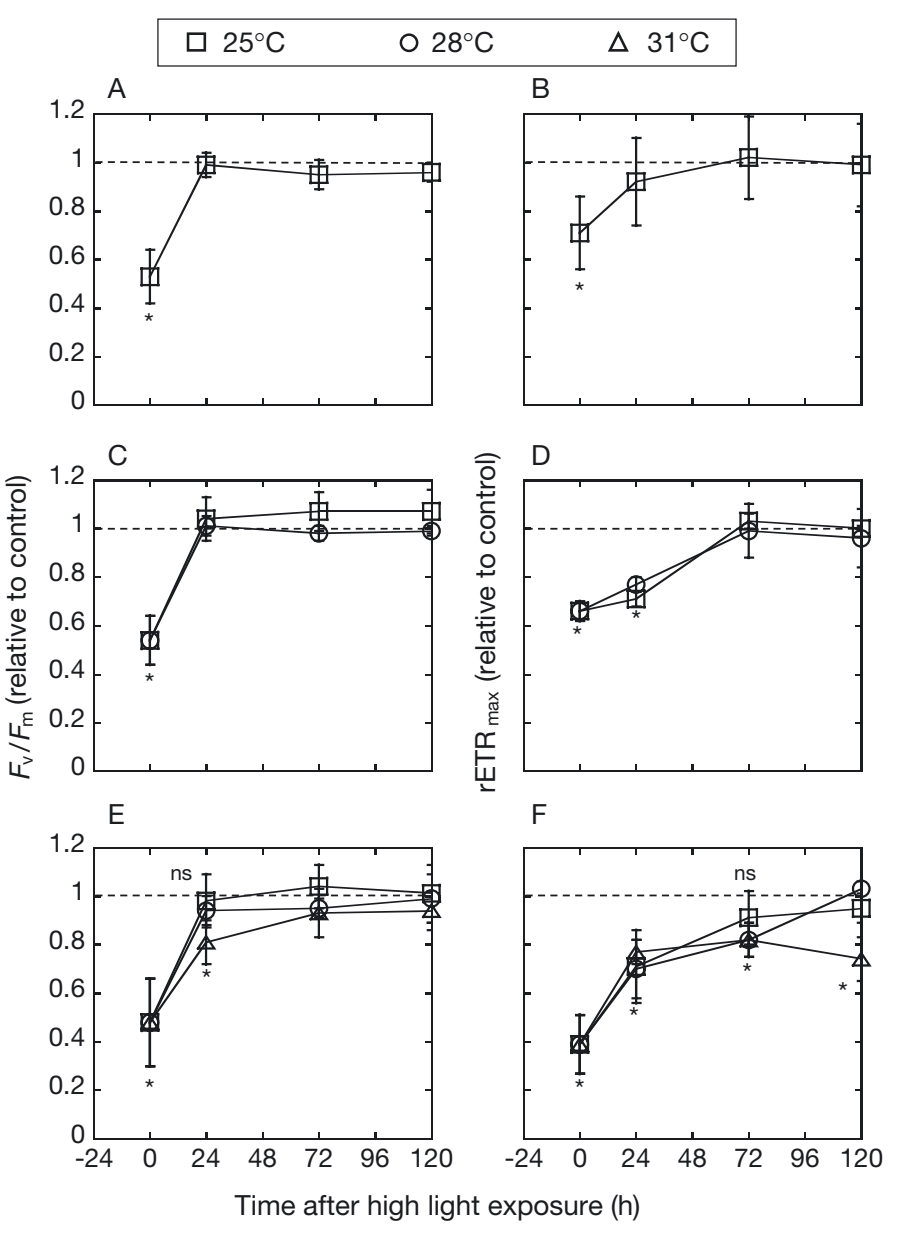

Fig. 4. Time course of recovery in $F_{\mathrm{v}} / F_{\mathrm{m}}$ and $\mathrm{rETR}_{\max }$ in symbiotic dinoflagellates of Montipora digitata exposed to high light $\left(1100 \mu \mathrm{mol}\right.$ photons $\left.\mathrm{m}^{-2} \mathrm{~s}^{-1}\right)$ for $3 \mathrm{~h}$. Details as in Fig. 3

non-exposed controls in both coral species investigated (Fig. 6 for Montipora digitata; data not shown for Pavona divaricata).

\section{Recovery under different temperature conditions}

The time course of recovery in the total Chl content in symbiotic dinoflagellates after high light exposure differed between Pavona divaricata and Montipora digitata (Fig. 5). In P. divaricata, the total Chl content returned to the control level within $24 \mathrm{~h}$ in all cases regardless of temperature during recovery (Fig. 5A,C,E). When the fragments of $M$. digitata exposed to high light at 25 and $28^{\circ} \mathrm{C}$ were allowed to recover at $25^{\circ} \mathrm{C}$, the total $\mathrm{Chl}$ content returned to the control level within $24 \mathrm{~h}$ (Fig. 5B,D). However, when the $28^{\circ} \mathrm{C}$-treated fragments were allowed to recover at $28^{\circ} \mathrm{C}$, it took longer, $72 \mathrm{~h}$, for the total $\mathrm{Chl}$ content to return to the control level (Fig. 5D). Transfer of the

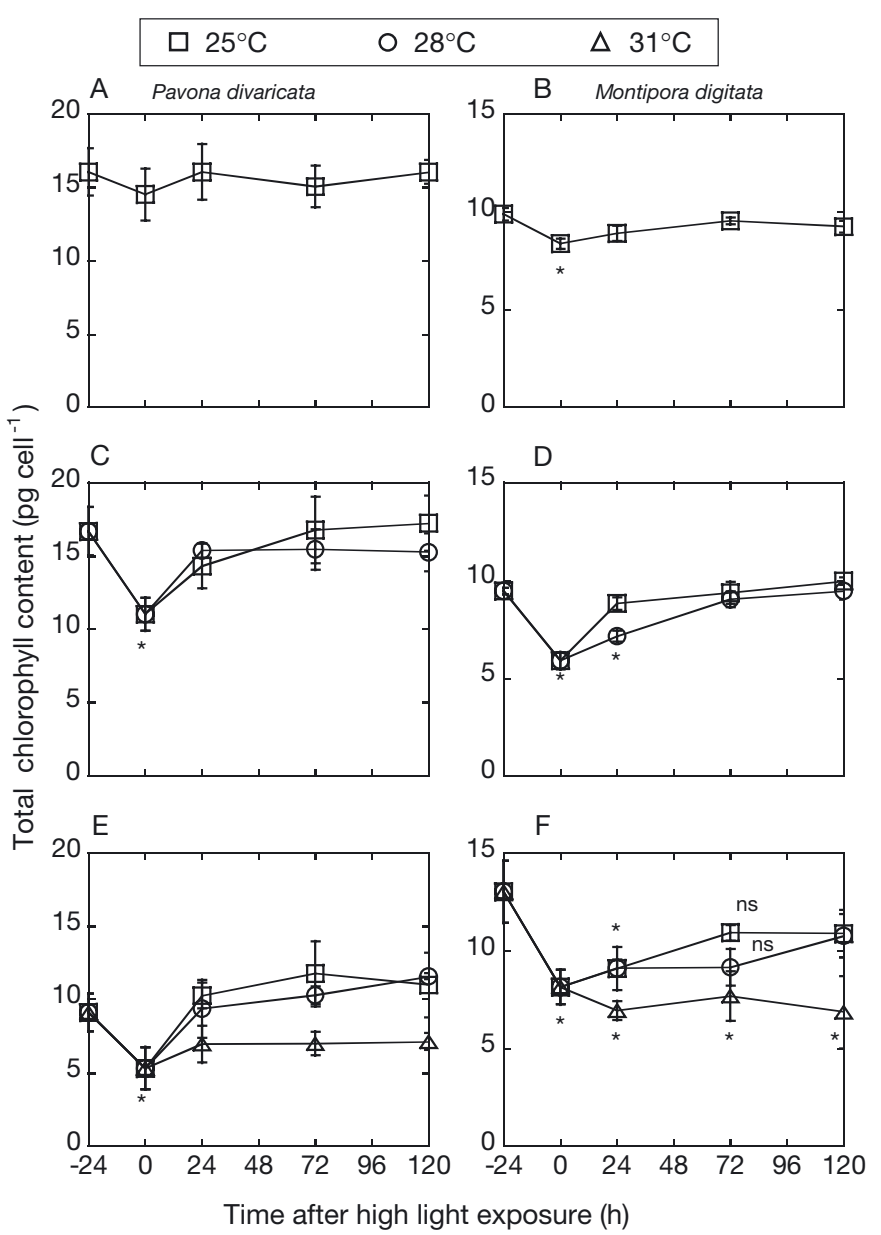

Fig. 5. Time course of recovery in the total Chl content in symbiotic dinoflagellates of Pavona divaricata and Montipora digitata exposed to high light (1100 $\mu \mathrm{mol}$ photons $\left.\mathrm{m}^{-2} \mathrm{~s}^{-1}\right)$ for $3 \mathrm{~h}$. Coral fragments were exposed to high light at $(\mathrm{A}, \mathrm{B}) 25,(\mathrm{C}, \mathrm{D})$ 28 , and $(\mathrm{E}, \mathrm{F}) 31^{\circ} \mathrm{C}$. Fragments were allowed to recover at 25 , 28 , and $31^{\circ} \mathrm{C}$. Means $\pm \mathrm{SD}(\mathrm{n}=4)$. ${ }^{*}$ Values significantly different from controls $(t$-test, $\mathrm{p}<0.05)$. ns: not significant

$31^{\circ} \mathrm{C}$-treated fragments of $M$. digitata after high light exposure to 25 and $28^{\circ} \mathrm{C}$ resulted in a complete recovery of the total $\mathrm{Chl}$ content within $72 \mathrm{~h}$ (Fig. 5F). The $\mathrm{Chl}$ content remained at a reduced level even $120 \mathrm{~h}$ after high light exposure in the $31^{\circ} \mathrm{C}$-treated fragments of $M$. digitata when they were kept at $31^{\circ} \mathrm{C}$ during the recovery period (Fig. 5F). Temperature during the recovery period had a significant effect (ANOVA, $F=$ 8.99, p < 0.01) on $\mathrm{Chl}$ content in the $31^{\circ} \mathrm{C}$-treated fragments of $M$. digitata and provided $17.0 \%$ (SF: $\mathrm{p}<0.01$ ) of Chl variation. There was no significant $(p>0.05)$ change in the total $\mathrm{Chl}$ content of non-exposed control coral fragments during the experimental period for both coral species.

Temperature during recovery had a significant (ANOVA, $F=56.24$, p < 0.05) effect on algal density in Montipora digitata fragments, and provided $81.0 \%$ 


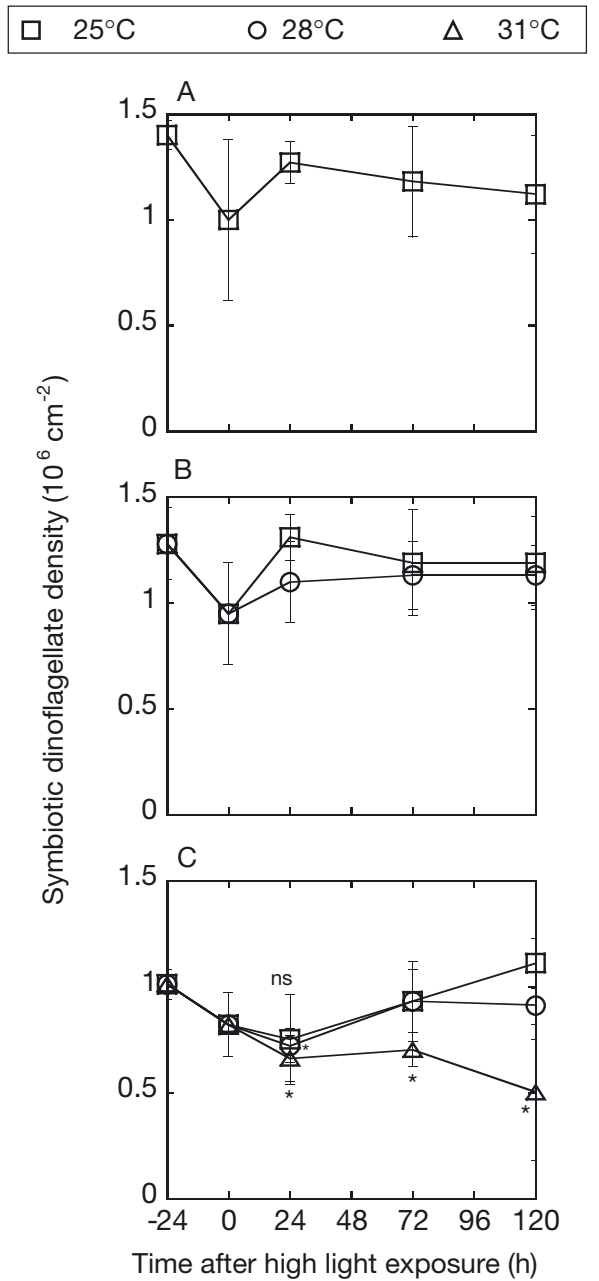

Fig. 6. Time course of recovery in the symbiotic dinoflagellate density of Montipora digitata exposed to high light $(1100 \mu \mathrm{mol}$ photons $\mathrm{m}^{-2} \mathrm{~s}^{-1}$ ) for $3 \mathrm{~h}$. Coral fragments were exposed to high light at (A) 25 , (B) 28 , and (C) $31^{\circ} \mathrm{C}$. Fragments were then allowed to recover at 25,28 , and $31^{\circ} \mathrm{C}$. Means $\pm \mathrm{SD}(\mathrm{n}=4)$. $*$ Values significantly different from controls $(t$-test, $\mathrm{p}<0.05)$

(SF: $\mathrm{p}<0.05)$ of its variation. When the fragments of $M$. digitata exposed to high light at $31^{\circ} \mathrm{C}$ were allowed to recover at 28 or $31^{\circ} \mathrm{C}$, significant $(\mathrm{p}<0.05)$ decline in the symbiotic dinoflagellate density was observed after $24 \mathrm{~h}$ (Fig. 6). The dinoflagellate density returned to the control level after $72 \mathrm{~h}$ at $28^{\circ} \mathrm{C}$, while it remained at a significantly lower level over the recovery period of $120 \mathrm{~h}$ at $31^{\circ} \mathrm{C}$ (Fig. 6C). No significant decrease in symbiotic dinoflagellate density was observed during the recovery period either in the fragments exposed to high light at 25 and $28^{\circ} \mathrm{C}$ (Fig. 6A,B) or in fragments that were exposed to high light at $31^{\circ} \mathrm{C}$ and allowed to recover at $25^{\circ} \mathrm{C}$ (Fig. 6C).

On the other hand, no change in symbiotic dinoflagellate density was detected in Pavona divaricata regardless of temperature during the recovery period (data not shown). Non-exposed controls showed no significant changes in dinoflagellate density at the respective temperatures during the course of the experiment for both coral species.

\section{DISCUSSION}

Recent studies have shown that elevated temperatures affect both the dark and light reactions of photosynthesis in symbiotic dinoflagellates of reef-building corals (Lesser 1996, Jones et al. 1998, Warner et al. 1999). If the recovery of dark reaction is slower than that of light reaction, limited availability of electron acceptors could result in an excess of electrons in the photosynthetic electron transport chain even under sub-saturating light levels. This may lead to production of active oxygen molecules, which are harmful to the photosynthetic apparatus of the algae as well as the host corals. Thus, differential recovery rates of dark and light reactions from damage due to temperature and light stresses might influence the susceptibility of corals to bleaching. This study tested the 'differential recovery' hypothesis and documented for the first time the difference in the rate of recovery between PSII function (photochemical efficiency, $F_{\mathrm{v}} / F_{\mathrm{m}}$ ) and photosynthetic capacity, (relative maximum electron transport rate, $\mathrm{rETR}_{\max }$ ) of symbiotic dinoflagellates in a bleaching susceptible coral, Montipora digitata, exposed to high temperature and strong light.

Exposing Pavona divaricata and Montipora digitata to high light for $3 \mathrm{~h}$ caused a significant reduction in photochemical efficiency, $F_{\mathrm{v}} / F_{\mathrm{m}}$, of in hospite dinoflagellates. Such a reduction during stress is considered to be associated with an imbalance between degradation and replacement of D1 reaction center protein causing accumulation of non-functional PSII, and resulting in a lower photosynthetic efficiency (Vasilikiotis \& Melis 1994). The degree of reduction in $F_{\mathrm{v}} / F_{\mathrm{m}}$ was independent of temperature during high light exposure in both species. However, the subsequent restoration of $F_{\mathrm{v}} / F_{\mathrm{m}}$ showed temperature dependency during the recovery period in both species. The $F_{\mathrm{v}} / F_{\mathrm{m}}$ values recovered completely within $24 \mathrm{~h}$ when the corals were returned to 25 or $28^{\circ} \mathrm{C}$ after high light exposure, while it took longer when $P$. divaricata and M. digitata were allowed to recover at $31^{\circ} \mathrm{C}$. Thus, the damage of PSII function and its recovery process appeared to be similar in the 2 corals. The slow recovery of $F_{\mathrm{v}} / F_{\mathrm{m}}$ at high temperature is consistent with the suggestion that re-synthesis of D1 reaction center protein was inhibited at high temperature (Warner et al. 1999). However, transient damage to D1 protein may serve for photoprotection as damaged reaction centers 
continue to trap light energy and to dissipate it as heat (Krause 1988), though Gorbunov et al. (2001) reported that the dynamic photoinhibition through D1 protein damage plays a minor role in photoprotection, when compared with non-photochemical quenching via down-regulation of PSII reaction centers and through xanthophyll cycle in light harvesting complexes.

On the other hand, there were apparent differences in sensitivity of photosynthetic capacity, $\mathrm{rETR}_{\max }$ in symbiotic dinoflagellates to temperature between the 2 coral species. The reduction in $\mathrm{rETR}_{\max }$ of Pavona divaricata was independent of temperature, and its recovery was almost complete $24 \mathrm{~h}$ after the stress treatment at all temperatures examined. It is likely that the high temperature level used in the present experiment is not stressful to $P$. divaricata, and increases in temperature of 1 to $2^{\circ} \mathrm{C}$ above normal do not permanently damage the dark reactions of symbiotic dinoflagellates in this species. In contrast, the extent of reduction in $\mathrm{rETR}_{\max }$ of Montipora digitata increased with increasing temperature during high light exposure, and recovery was much slower at 28 and $31^{\circ} \mathrm{C}$ than at $25^{\circ} \mathrm{C}$. This is in agreement with the previous experiments where increased temperature hampers photosynthetic performance of symbiotic dinoflagellates in corals, probably as a consequence of heat damage in the Calvin-Benson cycle reactions (Lesser 1996, Jones et al. 1998).

The present results showed that high light exposure produced significant reduction in both $F_{\mathrm{v}} / F_{\mathrm{m}}$ and $\mathrm{rETR}_{\max }$ of Pavona divaricata and Montipora digitata, while the time course of recovery of these parameters was different between corals studied. The recovery of $\mathrm{rETR}_{\max }$ was slower than that of $F_{\mathrm{v}} / F_{\mathrm{m}}$ in $M$. digitata at 28 and $31^{\circ} \mathrm{C}$, while $\mathrm{rETR}_{\max }$ and $F_{\mathrm{v}} / F_{\mathrm{m}}$ recovered almost in parallel in $P$. divaricata. A marked decrease in $\mathrm{rETR}_{\max }$ at high temperature and its slow recovery as compared with the recovery of PSII function (Fig. 4) are characteristic of $M$. digitata, which is more susceptible to bleaching than P. divaricata (Loya et al. 2001, Sakai pers. comm.). The reduced level of $\mathrm{rETR}_{\max }$ after full recovery of PSII function might indicate that electron transport beyond PSII was blocked probably by slowdown of the Calvin-Benson cycle. It is likely that the primary target of heat stress is enzymes catalyzing the operation of the Calvin-Benson cycle, as suggested in higher plants (Feller et al. 1998). If this is the case, high-energy electrons generated at PSII cannot be fully consumed in the carbon-fixation cycle. Extra high-energy electrons may react with adjacent oxygen molecules to produce active oxygen, which in turn cause damage or inactivation of photosynthetic components of symbiotic dinoflagellates (Lesser 1997). This typically results in a decrease in the overall photosynthetic rate (Richter et al. 1990), indicated by decreased yield $\left(F_{\mathrm{v}} / F_{\mathrm{m}}\right)$; a phenomenon also observed in the present study (Fig. 4E). Thus, the sensitivity of enzymes in the Calvin-Benson cycle to high temperature and the capacity to repair their damage may play an important role in determining the susceptibility of corals to bleaching. Corals sampled during bleaching events have been reported to exhibit decreased $\mathrm{Chl}$ content per algal cell and/or loss of symbiotic dinoflagellates (Porter et al. 1989, Fitt \& Warner 1995, Warner et al. 1996, Jones et al. 1998, 2000, Brown et al. 2002). Our results follow both trends, showing a marked decrease in symbiotic dinoflagellate density and $\mathrm{Chl}$ content when fragments of $M$. digitata exposed to high light were allowed to recover at $31^{\circ} \mathrm{C}$ (Figs. $5 \& 6$ ). The $F_{\mathrm{v}} / F_{\mathrm{m}}$ values showed significant but incomplete recovery throughout the first $24 \mathrm{~h}$ after stressed corals were transferred to $31^{\circ} \mathrm{C}$ (Fig. 4E). This result is consistent with observations made by Jones et al. (2000) on Plesiastrea versipora, in which, despite the significant recovery of $F_{\mathrm{v}} / F_{\mathrm{m}}$ after heat stress, the loss of symbiotic algae occurred during the first few days of the recovery period. The explanation for this phenomenon might be incomplete recovery of maximal electron transport rate for a prolonged time following exposure of corals to stress. In the present experiment, signs of bleaching were observed when $\mathrm{rETR}_{\max }$ remained substantially lower than initial levels throughout the $120 \mathrm{~h}$ monitoring period and, thus, the difference in the recovery rate between $\mathrm{rETR}_{\max }$ and $F_{\mathrm{v}} / F_{\mathrm{m}}$ was largest. The present results support the differential recovery hypothesis described above. This hypothesis is not only consistent with the 'photoinhibition' hypothesis proposed by Hoegh-Guldberg (1999) but also extends their suggestion to the recovery phase. Temperature dependency of repair process of enzymes involved in carbon fixation might actually influence bleaching susceptibility of shallow-water corals, which can be exposed to sea-surface temperatures higher than normal summer maxima from a few days to weeks (e.g. Hoegh-Guldberg 1999).

Gradual temperature increase to $31^{\circ} \mathrm{C}$ during the $5 \mathrm{~d}$ acclimation period resulted in lower $\mathrm{Chl}$ content per algal cell and $\mathrm{rETR}_{\max }$ values in Pavona divaricata, while it increased pigments and $\mathrm{rETR}_{\max }$ slightly but significantly in Montipora digitata. It is not clear why the $\mathrm{rETR}_{\max }$ values increased in $M$. digitata after acclimation to $31^{\circ} \mathrm{C}$, as the $3 \mathrm{~h}$ treatment at $31^{\circ} \mathrm{C}$ under high light decreased $\mathrm{rETR}_{\max }$ to a greater extent than at other temperatures. It is, however, likely that physiological parameters measured after 5d acclimation reflected changes due to acclimation to high temperature as the possible effect of photoacclimation to low light was avoided by maintenance of shallow-watercollected corals under the shade a few weeks before the experiment. An interesting aspect of temperature 
acclimation of algal photosynthesis is the general similarity between temperature acclimation and photoacclimation (Davison 1991). Earlier, it was shown that high-temperature-acclimated algae had a high content of photosynthetic pigments and increased photosynthetic capacity (Zupan \& West 1990, Machalek et al. 1996, Schofield et al. 1998), resembling those characteristics of photoacclimation to low light. It seems that the high temperature acclimation response of $M$. digitata (increased $\mathrm{rETR}_{\max }$ and algal Chl content) followed the same trend, and as a result this increased its susceptibility to further high light exposure, the general reaction for shade-adapted plants exposed to natural solar radiation (Powles 1984).

The 2 investigated corals harbor physiologically different symbiotic algae, though both corals live in shallow-water areas, which are well exposed to solar radiation. There is evidence for a high diversity of endosymbiotic dinoflagellates in coral species (LaJeunesse 2001). Previous studies have shown that physiological (Brown et al. 1994, 2002, Warner at al. 1999) and genetic differences (Rowan et al. 1997, Glynn et al. 2001) in algal symbionts play an important role in determining bleaching susceptibility of corals. Pavona divaricata might have adopted the strategy to harbor symbiotic dinoflagellates that possess a strong ability to repair photosynthetic capacity to cope with high irradiance at low depth during thermal stress. On the other hand, Montipora digitata might have adopted the strategy to expel the dinoflagellates from the host tissue when they become harmful by producing active oxygen species (Lesser 1997). Although M. digitata is one of the survivors of 1998 mass bleaching event in Okinawa, Sugihara et al. (1999) reported that colonies of $M$. digitata showed partial and variable bleaching in Kikai-jima, Ryukyus Islands, in 1998. It is likely that symbiotic algae remained in shaded part of colonies of M. digitata and proliferate quickly to repopulate the bleached colonies to enable this species to survive.

\section{CONCLUSIONS}

Our results clearly show that the process of recovery from thermal stress is different among corals species. In Pavona divaricata, where PSII function, $F_{\mathrm{v}} / F_{\mathrm{m}}$ and photosynthetic capacity, $\mathrm{rETR}_{\max }$, recovered in parallel, no sign of bleaching was detected. In Montipora digitata, bleaching was more or less correlated with significant delay of recovery of $\mathrm{rETR}_{\max }$ as compared with $F_{\mathrm{v}} / F_{\mathrm{m}}$. The delay in the recovery of $\mathrm{rETR}_{\max }$ after full restoration of $F_{\mathrm{v}} / F_{\mathrm{m}}$ indicates incomplete recovery of damage in the Calvin-Benson cycle. The present findings strongly suggest that high temperature affects the rate of recovery of the carbon fixation cycle and that the ability of symbiotic dinoflagellates to repair damage determines susceptibility of corals to bleaching. Hence, the optimization of regulatory mechanisms to reduce the required time for recovery from high light stress might be an important strategy for bleaching tolerant coral species to cope with high irradiance at low depth during thermal stress.

Acknowledgements. This research was partly supported by Grant-in-Aid for Scientific Research from the Japan Society for Promotion of Science. The authors are thankful to Dr. A. Baird and Prof. E. Titlyanov for their valuable comments on the manuscript.

\section{LITERATURE CITED}

Bhagooli R, Hidaka M (2002) Physiological responses of the coral Galaxea fascicularis and its algal symbiont to elevated temperature. Galaxea JCRS 4:33-42

Bose S, Herbert SK, Fork DC (1988) Fluorescence characteristics of photoinhibition and recovery in a sun and a shade species of the red algal genus Porphyra. Plant Physiol 86: 946-950

Brown BE (1997) Coral bleaching: causes and consequences. Coral Reefs 16:129-138

Brown BE, Dunne RP, Scoffin TP, Le Tissier MDA (1994) Solar damage in intertidal corals. Mar Ecol Prog Ser 105:219-230

Brown BE, Dunne RP, Goodson MS, Douglas AE (2002) Experience shapes the susceptibility of a reef coral to bleaching. Coral Reefs 21:119-126

Davison IR (1990) Environmental effects on algal photosynthesis: temperature. J Phycol 27:2-8

Demmig-Adams B, Adams WW III (1992) Photoprotection and other responses of plants to high light stress. Annu Rev Plant Physiol Mol Biol 43:599-626

Feller U, Crafts-Brandner J, Salvucci ME (1998) Moderately high temperatures inhibit ribulose-1,5-bisphosphate carboxylase/oxygenase (Rubisco) activase-mediated activation of Rubisco. Plant Physiol 116:539-546

Fitt WK, Cook CB (2001) Photoacclimation and the effect of the symbiotic environment on the photosynthetic response of symbiotic dinoflagellates in the tropical marine hydroid Myrionema abmboinense. J Exp Mar Biol Ecol 256:15-31

Fitt WK, Warner ME (1995) Bleaching patterns of four species of Caribbean reef corals. Biol Bull 187:298-307

Fitt WK, Brown BE, Warner ME, Dunne RP (2001) Coral bleaching: interpretation of thermal tolerance limits and thermal thresholds in tropical corals. Coral Reefs 20:51-65

Glynn PW (1993) Coral reef bleaching: ecological perspectives. Coral Reefs 12:1-17

Glynn PW, Mate JI, Baker AC, Calderon MO (2001) Coral bleaching and mortality in Panama and Ecuador during the 1997-1998 El Nino-southern oscillation event: spatial/ temporal patterns and comparisons with the 1982-1983 event. Bull Mar Sci 69:79-109

Gorbunov MY, Kolber AS, Lesser MP, Falkowski PG (2001) Photosynthesis and photoprotection in symbiotic corals. Limnol Oceanogr 46(1):75-85

Hoegh-Guldberg O (1999) Climate change, coral bleaching and the future of the world's coral reefs. Mar Freshw Res 50:839-866

Hoegh-Guldberg O, Jones RJ (1999) Photoinhibition and photoprotection in symbiotic dinoflagellates from reef- 
building corals. Mar Ecol Prog Ser 183:73-86

Iglesias-Prieto RJL (1997) Temperature-dependent inactivation of photosystem II in symbiotic dinoflagellates. Proc 8th Int Coral Reef Symp 2:1313-1318

Iglesias-Prieto RJL, Matta JL, Robbins WA, Trench RK (1992) Photosynthesis response to elevated temperature in the symbiotic dinoflagellate Symbiodinium microadriaticum in culture. Proc Natl Acad Sci USA 89:10302-10305

Jeffrey SW, Humphrey GE (1975) New spectrophotometric equations for determining chlorophylls $a, b, c_{1}$ and $c_{2}$ in higher plants, algae and natural phytoplankton. Biochem Physiol Pflanz 167:191-194

Johannes RE, Wiebe WJ (1970) A method for determination of coral tissue biomass and composition. Limnol Oceanogr 15:822-824

Jones RJ, T, Hoegh-Guldberg O, Larcum AWD, Schreiber U (1998) Temperature induced bleaching of corals begins with impairment of the $\mathrm{CO}_{2}$ fixation mechanism in zooxanthellae. Plant Cell Environ 21:1219-1230

Jones RJ, Ward S, Amri AY, Hoegh-Guldberg O (2000) Changes in quantum efficiency of Photosystem II of symbiotic dinoflagellates of corals after heat stress, and of bleached corals sampled after the 1998 Great Barrier Reef mass bleaching events. Mar Freshw Res 51:63-71

Krause GH (1988) Photoinhibition of photosynthesis: an evaluation of damaging and protective mechanisms. Physiol Planta 74:566-574

LaJeunesse TC (2001) Investigating the biodiversity, ecology, and phylogeny of endosymbiotic dinoflagellates in the genus Symbiodinium using the ITS region: in search of a 'species' level marker. Phycol 37:886-880

Lesser MP (1996) Elevated temperatures and ultraviolet radiation cause oxidative stress and inhibit photosynthesis in symbiotic dinoflagellates. Limnol Oceanogr 41:271-283

Lesser MP (1997) Oxidative stress causes coral bleaching during exposure to elevated temperatures. Coral Reefs 16: 187-192

Loya Y, Sakai K, Yamazato K, Nakano Y, Sambali H, van Woesik R (2001) Coral bleaching: the winners and the losers. Ecol Lett 4:122-131

Machalek KM, Davison IR, Falkowski PG (1996) Thermal acclimation and photoacclimation of photosynthesis in the brown alga Laminaria saccharina. Plant Cell Environ 19: 1005-1016

Oquist G, Anderson JM, McCaffery S, Chow WS (1992) Mechanistic differences in photoinhibition of sun and shade plants. Planta 188:538-544

Powles SB (1984) Photoinhibition of photosynthesis induced by visible light. Annu Rev Plant Physiol 35:15-44

Porter JW, Fitt WK, Spero HJ, Rogers CS, White MW (1989)

Editorial responsibility: Otto Kinne (Editor),

Oldendorf/Luhe, Germany
Bleaching in reef corals: physiological and stable isotopic responses. Proc Natl Acad Sci USA 86:9342-9346

Richter M, Ruhle W, Wild A (1990) Studies on the mechanism of photosystem II photoinhibition. The involvement of toxic oxygen species. Photosynth Res 24:237-244

Rowan R, Knowlton N, Baker A, Jara J (1997) Landscape ecology of algal symbionts creates variation in episodes of coral bleaching. Nature 388:265-269

Saxby T, Dennison WC, Hoegh-Guldberg O (2003) Photosynthetic responses of the coral Montipora digitata to cold temperature stress. Mar Ecol Prog Ser 248:85-97

Schofield O, Crzymski J, Moline M, Jovine V (1998) Impact of temperature acclimation on photosynthesis in the toxic red-tide dinoflagellate Alexandrium fundyense (Ca28). J Plankton Res 20:1241-1258

Schreiber U, Bilger W, Neubauer C (1994) Chlorophyll fluorescence as a non intrusive indicator for rapid assessment of in vivo photosynthesis. In: Schluze ED, Caldwell MM (eds) Ecophysiology of photosynthesis. Springer-Verlag, Berlin, p 49-70

Snedecor DU (1961) Statistical methods in application to the investigations in agriculture and biology. High School, Moscow, p 35-43 (in Russian)

Stimson J, Kinzie RA (1991) The temporal pattern and rate of release zooxanthellae from the reef coral Pocillopora damicornis (Linnaeus) under nitrogen-enrichment and control conditions. J Exp Mar Biol Ecol 153:63-74

Sugihara K, Iryu Y, Nakamori T (1999) Coral bleaching, geological ranges and adaptation to high sea surface temperatures. Galaxea JCRS 1:89-95

Titlyanov EA, Titlyanova TV, Leletkin VA, Tsukahara J, Van Woesik R, Yamazato K (1996) Degradation of zooxanthellae and regulation of their density in hermatypic corals. Mar Ecol Prog Ser 139:167-178

Vasilikiotis C, Melis A (1994) Photosystem II reaction center damage and repair cycle: chloroplast acclimation strategy to irradiance stress. Proc Natl Acad Sci USA 91:7222-7226

Warner ME, Fitt WK, Schmidt GW (1996) The effects of elevated temperature on the photosynthetic efficiency of zooxanthellae in hospite from four different species of reef coral: a novel approach. Plant Cell Environ 19:291-299

Warner ME, Fitt WK, Schmidt GW (1999) Damage to photosystem II in symbiotic dinoflagellates: a determinant of coral bleaching. Proc Natl Acad Sci USA 96:8007-8012

Winters G, Loya Y, Rottgers R (2003) Photoinhibition in shallow-water colonies of the coral Stylophora pistillata as measured in situ. Limnol Oceanogr 48:1388-1393

Zupan JR, West JA (1990) Photosynthetic responses to light and temperature of heteromorphic marine alga Mastocarpus papillatus (Rhodophyta). J Phycol 26:232-239

Submitted: April 23, 2003; Accepted: November 25, 2003

Proofs received from author(s): February 16, 2004 